\title{
Karakteristik beberapa Galur Mutan Sorgum dari Potensi Produksi Gas dan Degradabilitas secara In-vitro
}

\author{
Sorgum Mutant Lines Characteristics Based on In-vitro Gas \\ Production and Degradability Value
}

\author{
Firsoni dan Wahidin Teguh Sasongko \\ Pusat Aplikasi Isotop dan Radiasi, BATAN \\ Jl. Lebak Bulus Raya No. 49 Jakarta 12440 \\ Email : firsoni@batan.go.id
}

\begin{abstract}
ABSTRAK
Teknik produksi gas digunakan untuk mengetahui perbandingan beberapa jenis galur mutan sorgum yang dihasilkan oleh BATAN sebagai pakan ruminansia. 8 jenis daun galur mutan sorgum dan rancangan acak lengkap digunakan dalam pengujian ini. Untuk melihat perbandingan antara perlakuan dilakukan uji anova dan uji lanjut BNT bila pengaruh perlakuan signifikan. Sampel ditimbang $375 \mathrm{mg}$, dimasukkan ke dalam syringe glass $100 \mathrm{ml}$ ditambah $30 \mathrm{ml}$ media campuran cairan rumen dengan buffer bicarbonat dan diinkubasi pada suhu $39^{\circ} \mathrm{C}$ selama $24 \mathrm{jam}$. Variabel yang diukur adalah produksi gas setelah $0,2,4,6,8,19,12,24$ dan 48 jam inkubasi, potensi produksi gas, degradabilitas bahan kering (DBK) dan organik (DBO). Hasil yang diperoleh menunjukkan produksi gas, potensi produksi gas dan degradabilitas yang dihasilkan berbeda nyata $(\mathrm{P}<0,05)$. Produksi gas tertinggi setelah 24 dan 48 jam adalah perlakuan $\mathrm{H}$ dan B yaitu 57,59 dan $71,75 \mathrm{ml} / 375 \mathrm{mg} \mathrm{BK}$, sementara itu terendah adalah perlakuan I dan $\mathrm{G}$ yaitu 50,33 dan $54,92 \mathrm{ml} / 375 \mathrm{mg}$ BK. Potensi produksi gas yang dihasilkan tertinggi adalah perlakuan B yaitu $85,46 \mathrm{ml} / 375 \mathrm{mg}$ BK dan terendah adalah perlakuan $\mathrm{G}$ yaitu $56,74 \mathrm{ml} / 375 \mathrm{mg} \mathrm{BK}$, sementara itu persentase produksi gas selama 24 jam tertinggi adalah perlakuan G yaitu $82,45 \%$ dan terendah perlakuan B yaitu 62,24\%. Degradabilitas bahan kering (DBK) tertinggi setelah 24 dan 48 jam inkubasi adalah perlakuan D dan A yaitu 54,45 dan $67,31 \%$, sementara itu terendah adalah perlakuan G yaitu 50,85 dan 58,93\%. Degradabilitas bahan organik (DBO) tertinggi tertinggi setelah 24 dan 48 jam inkubasi adalah perlakuan D dan B yaitu 54,13 dan $69,13 \%$, sementara itu terendah adalah perlakuan G yaitu 50,67 dan 58,93\%. Secara umum ada dua jenis galur mutan sorgum hasil iradiasi yaitu mudah terdegradasi sebelum 24 jam dan setelah 24 jam, sehingga bisa digunakan untuk pedoman pemberian pakan untuk ruminansia.
\end{abstract}

Kata kunci : Produksi gas, potensi produksi gas, degradabilitas, in-vitro, jerami galur mutan sorghum

\begin{abstract}
Gas production techniques are used to compare sorghum mutant lines stover produced by BATAN as ruminants feed. 8 types of lines and complete randomized design with least significan difference (LSD) test was used to compare treatments. Samples were weighted $375 \mathrm{mg}$, put into $100 \mathrm{ml}$ syringe glass and added by $30 \mathrm{ml}$ bicarbonate buffer media then incubated at $39^{\circ} \mathrm{C}$ for 24 hours. Parameters determined were gas production after $0,2,4,6,8,19,12,24$ and 48 hours incubation, gas potential, dry matter (DBK) and organic matters (DBO) degradability. The result showed that gas production, gas potential and degradability were significantly different $(\mathrm{P}<0.05)$. The highest gas production after 24 and 48 hours was treatment $\mathrm{H}$ and $\mathrm{B}(57,59$ and $71,75 \mathrm{ml} / 375 \mathrm{mg} \mathrm{BK})$, while the lowest was treatment $\mathrm{I}$ and $\mathrm{G}(50,33$ and $54,92 \mathrm{ml} / 375 \mathrm{mg} \mathrm{BK})$. The highest gas production potential is treatment $\mathrm{B}(85,46 \mathrm{ml} / 375 \mathrm{mg} \mathrm{BK})$ and the lowest is $\mathrm{G}(56,74 \mathrm{ml} / 375 \mathrm{mg} \mathrm{BK})$, meanwhile the highest percentage of gas production during 24 hours is highest is treatment $\mathrm{G}(82,45 \%)$ and the lowest is B $(62.24 \%)$. The highest degradability of dry matter (DBK) after 24 and 48 hours incubation was treatment D and A (54,45 and 67,31\%), while the lowest was treatment $\mathrm{G}(50,85$ and $58,93 \%)$. The highest DBO after 24 and 48 hour incubation was treatment D and B $(54,13$ and $69,13 \%)$, while the lowest was treatment $\mathrm{G}(50,67$ and 58,93\%). Generally there are two types of irradiated sorghum mutant lines that are easily degraded before 24 hours and after 24 hours, so they can be used for feeding guidelines for ruminants.
\end{abstract}

Keywords : Gas production, gas potential, degradability, in-vitro, sorghum mutan line stover 


\section{PENDAHULUAN}

Peningkatan kualitas pakan ternak sangat dibutuhkan akhir-akhir ini, karena ketersediaannya yang semakin terbatas. Salah satu cara adalah dengan mengetahui nilai nutrisi bahan pakan yang akan dipakai di dalam formula pakan. Dengan mengetahui nilai nutrisi masing-masing bahan pakan akan memudahkan di dalam menyusun formula pakan. Selain itu juga bisa dilakukan teknik in-vitro untuk mengetahui karakteristik dan kemampuan biologis suatu pakan seperti in-vitro gas test $[1,2]$. Pemakaian teknik in vitro produksi gas sangat cocok digunakan untuk membandingkan kualitas beberapa jenis pakan ruminansia [3, 4]. Produksi gas selama inkubasi merupakan produk buangan dari fermentasi substrat didalam tabung seperti gas $\mathrm{CH}_{4}, \mathrm{CO}_{2}, \mathrm{O}_{2}$, $\mathrm{H}_{2} \mathrm{~S}$ dan gas lainnya. Produksi gas menggambarkan tingkat proses fermentasi yang terjadi, sehingga diperoleh informasi mengenai laju produksi gas sesuai dengan sifat kimia bahan pakan yang diujikan. Informasi ini juga erat kaitannya dengan proses fermentasi dan degradasi substrat didalam tabung fermentor selama inkubasi. Analisa dengan teknik produksi gas merupakan salah satu cara untuk evaluasi kualitas pakan yang cukup murah dan bermanfaat $[5,6]$.

In-vitro Gas Test adalah salah satu metode pengujian sederhana yang dapat dipilih untuk mengukur kemampuan produksi gas, degradabilitas dan produksi bimassa mikroba di dalam rumen hewan ruminansia dengan lebih cepat dibandingkan dengan pengujian langsung ke hewan percobaan. Metode ini merupakan hasil penyempurnaan dari metode in-vitro sebelumnya, dengan mengukur volume gas yang dihasilkan sebagai parameter untuk menilai degradabilitas [7]. Kelebihan metode ini dapat memperlihatkan pakan yang paling bagus secara langsung, dari hasil produksi gas dan degradabilitasnya serta dapat melihat pengaruh anti nutrisi yang dikandung pakan seperti tanin dan saponin.

Sorgum merupakan salah satu tanaman serealia yang potensial sedang dikembangkan BATAN dengan banyak jenis galur mutan yang sudah dihasilkan [15]. Sorgum toleran terhadap tanah yang kurang subur atau tanah kritis, sehingga lahan-lahan yang kurang produktif atau lahan tidur bisa ditanami serta toleran terhadap kekeringan dan genangan air, dapat berproduksi pada lahan marginal serta relatif tahan terhadap gangguan hama dan penyakit [8]. Untuk mendapatkan hasil maksimal, sorgum sebaiknya ditanam pada musim kemarau karena sepanjang hidupnya memerlukan sinar matahari penuh [9]. Biji Sorgum mengandung 70\% karbohidrat, 8$12 \%$ protein setara dengan terigu dan lebih tinggi dibandingkan beras yang mempunyai protein 6$10 \%$ serta sorgum kaya mineral esensial seperti $\mathrm{P}$, $\mathrm{Mg}, \mathrm{Ca}, \mathrm{Fe}, \mathrm{Zn}, \mathrm{Cu}, \mathrm{Mn}$, Mo dan $\mathrm{Cr}$ [10]. Ketersediaan biji sorgum, kalah banyak dibandingkan daun dan batang sorgum, sehingga potensi daun sorgum semakin baik untuk dijadikan pakan ternak. Daun sorgum mengandung nutrisi yang tinggi diantaranya kandungan protein kasar yang dapat mencapai $15.6-16,87 \%$ pada 100 hari setelah tanam $[11,12$, 13], sehingga sangat cocok untuk dimanfaatkan menjadi pakan ternak. Daun sorgum yang dipanen setelah 90 hari sangat tepat untuk dijadikan pakan ternak [14]. Teknik pemuliaan mutasi menghasilkan banyak variasi galur mutan sorgum, tentunya dengan produksi, daya tahan dan kandungan nutrisi yang bervariasi, akibat pengaruh irradiasi yang diberikan [15]. Selain uji produktifitas yang biasa dilakukan untuk pemuliaan tanaman, galur sorgum juga perlu dikaji kualitas daun/jerami sorgum untuk pakan ternak.

Untuk itu dilakukan penelitian yang bertujuan untuk memilih galur sorgum yang terbaik secara cepat dengan membandingkan karakteristik terbaik daun galur mutan sorghum dengan teknik in-vitro produksi gas.

\section{BAHAN DAN METODE}

\section{Bahan dan peralatan}

Penelitian ini menguji 9 jenis galur mutan sorgum (Sorghum bicolor) hasil pemuliaan mutasi di Pusat Aplikasi Isotop dan Radiasi (PAIR) BATAN yaitu A: BKL/01/50, B: BKL/01/K, C: BKL/01/30, D: UP/40, E: UP/20, F: UPCASI (k), G: ET-35, H: ET-20 dan I: ET-25 yang diperoleh dari hasil seleksi penelitian tanaman sorgum di BATAN menggunakan radiasi sinar gamma Cobalt-60. Bagian tanaman yang digunakan adalah bagian jerami sorgum yang meliputi bagian daun dan batang setelah panen yang dicacah terlebih dahulu, selanjutnya dikeringkan di oven selama 3-4 hari pada suhu $60^{\circ} \mathrm{C}$ dan setelah kering digiling dan disaring $<1 \mathrm{~mm}$. Cairan rumen yang dipakai adalah rumen kerbau yang diambil segar melalui cannulae, diblender dan disaring dengan 
kain kasa yang bersih. Media inkubasi terdiri dari

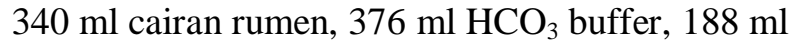
larutan makromineral, $0,12 \mathrm{ml}$ larutan mikromineral $0,12 \mathrm{ml}, 0,5 \mathrm{ml}$ larutan rezasurin dan larutan pereduksi sebanyak $31 \mathrm{ml}$.

Peralatan yang dipakai adalah syringe glass $100 \mathrm{ml}$, waterbath, timbangan neraca digital, dispenser, termometer, NDS reflux, crucible filter, oven dan furnece.

\section{In-vitro produksi gas}

Sehari sebelum kegiatan dilakukan penimbangan sampel $375 \pm 5 \mathrm{mg}$ dan dimasukkan ke dalam syringe glass ukuran $100 \mathrm{ml}$, selanjutnya dimasukkan piston yang sudah dilumuri sedikit vaseline agar memudahkan untuk mengukur gas yang dihasilkan. Syringe glass disimpan rapi di rak sesuai nomor. Media buffer disiapkan dengan mencampurkan larutan $\mathrm{HCO}_{3}$ buffer, makromineral, mikromineral, rezasurin dan ditambahkan $564 \mathrm{ml}$ aquades, diaduk merata dengan magnetic stirrer terakhir diberi gas $\mathrm{CO} 2$ secukupnya kemudian labu ditutup parafilm untuk keperluan besok. Bahan pereduksi juga disiapkan yaitu dengan menimbang $300 \mathrm{mg} \mathrm{Na}_{2} \mathrm{~S}$ dan disimpan terpisah serta menyiapkan larutan $\mathrm{NaOH}$ $1 \mathrm{M}$ sebanyak $2 \mathrm{ml}$. Peralatan yang disiapkan adalah dispenser dan pemanasan waterbath $39^{\circ} \mathrm{C}$.

Pagi hari besok, disiapkan larutan pereduksi dengan mencampurkan $\mathrm{Na}_{2} \mathrm{~S}, \mathrm{NaOH}$ dan $31 \mathrm{ml}$ Aquades, diaduk sampai $\mathrm{Na}_{2} \mathrm{~S}$ larut, selanjutnya larutan dicampurkan ke dalam media buffer sehingga merubah warna biru menjadi pink sambil diaduk dengan stirrer dan dialiri gas $\mathrm{CO}_{2}$, setelah warna pink berubah menjadi bening dimasukkan cairan rumen kerbau segar yang baru diambil dan telah disaring sebanyak $340 \mathrm{ml}$.

Setiap syringe glass berisi $375 \mathrm{mg}$ sampel ditambahkan $30 \mathrm{ml}$ media cairan rumen yang sudah ditambahkan larutan buffer bicarbonat dan diinkubasi di dalam waterbath $39^{\circ} \mathrm{C}$. Dicatat produksi gas selama $0,2,4,6,12$ dan 24 jam inkubasi. Setelah diinkubasi 24 jam, syringe glass didinginkan diantara batu es untuk menghentikan aktifitas mikroba.

Parameter yang diukur adalah produksi gas selama inkubasi $0,2,4,6,8,10,12,24,48,72$ dan 96 jam dan laju degradabilitas bahan kering dan bahan organik selama $2,4,6,8,10,12,24,48,72$ dan 96 jam inkubasi.

\section{Pengukuran degradabilitas}

Cairan rumen setelah inkubasi 24 jam ditambahkan dengan larutan NDS (Neutral Detergent Solution) dan di-reflux selama 1,5 jam kemudian disaring dengan crucible glass, dikeringkan di dalam oven $105^{\circ} \mathrm{C}$ semalam dan ditimbang sehingga diperoleh pakan yang tidak terdegradasi sebenarnya (x). Crucible glass ini dimasukkan ke dalam furnece dan dibakar pada $600^{\circ} \mathrm{C}$ selama 6-7 jam sehingga diperoleh berat abu (y) $[12,13]$.

$\mathrm{DBK}=\frac{z-x}{z} \times 100 \% \quad \mathrm{DBO}=\frac{w-(x-y)}{w} \times 100 \%$

Dimana: DBK: degradabilitas bahan kering, DBO: degradabilitas bahan organik, z: berat bahan kering sampel, w: berat bahan organik sampel; $\mathrm{x}$ : berat residu setelah oven dan y: berat abu setelah furnece.

\section{Uji statistik}

Penelitian ini menggunakan Rancangan Acak Lengkap (RAL) dengan 9 perlakuan dan 4 ulangan. Model statistik yang digunakan adalah sebagai berikut:

$$
\mathrm{Y}_{\mathrm{ij}}=\mu+\alpha_{\mathrm{i}}+\varepsilon_{\mathrm{ij}}
$$

Y adalah variable terikat, $\mu$ adalah rerata perlakuan, $\alpha_{i}$ adalah pengaruh jenis galur mutan sorgum sedangkan $\varepsilon_{\mathrm{ij}}$ adalah pengaruh acak/faktor error. Data yang diperoleh dianalisis dengan analisis ragam analysis of variance (ANOVA) dilanjutkan dengan uji Least Significant Difference (LSD) [16] pada taraf kepercayaan $\mathrm{P}<0,05$. Analisis data dilakukan secara manual dengan program microsoft excel.

Pengukuran produksi gas setelah 24 jam (48, 72 dan 96 jam) dilakukan menggunakan persamaan eksponensial menggunakan program NEWAY® berdasarkan persamaan [17]:

$$
P=a+b\left(1-e^{-k t}\right)
$$

Dimana $(a+b)$ adalah potensi produksi gas yang dihasilkan, $\mathrm{k}$ adalah laju produksi gas secara konstan per $t$ satuan waktu. Persamaan ini juga digunakan untuk melihat laju degradabilitas pakan pada waktu 2, 4, 6, 8, 10, 12, 24, 48, 72 dan 96 jam. Demikian juga dengan laju degradabalitas pada waktu 2, 4, 6, 8, 10, 12, 24, 48, 72 dan 96 
jam, dengan memanfaatkan persamaan diatas dari data degradabilitas selama 24 jam inkubasi.

\section{HASIL DAN PEMBAHASAN}

\section{Produksi gas}

Hasil pengukuran produksi gas 2, 4, 6, 8, 10, $12,24,48,72$, dan 96 jam menggunakan rumus $\mathbf{P}=\mathbf{a}+\mathbf{b}\left(\mathbf{1}-\mathbf{e}^{-\mathbf{k t}}\right)$ dapat dilihat pada Tabel 1. Produksi gas tertinggi selama 24 jam waktu inkubasi dihasilkan oleh perlakuan galur ET-10 (perlakuan $\mathrm{H})$ yaitu $57,59 \mathrm{ml}$, sementara terendah dihasilkan ET-35 (perlakuan G) yaitu 46,76 ml. Setiap galur sorghum menghasilkan produksi gas yang berbeda nyata pada setiap pengambilan data. Produksi gas tertinggi sampai 24 jam secara nyata $(\mathrm{P}<0,05)$ dihasilkan secara konstan dari perlakuan $\mathrm{H}$, tetapi produksi gas tertinggi secara nyata dihasilkan galur BKL/01/K dari 48, 72 dan 96 jam inkubasi (Tabel 1). Keragaman produksi gas yang dihasilkan disebabkan oleh sifat biologi dan kimia galur mutan galur mutan sorgum yang diuji. Irradiasi gamma menghasilkan keragaman tunas tanaman sorgum [15]. Selain itu kandungan anti nutrisi seperti asam penol, flavonoid, dan tannin $[18,19]$ juga menghambat beberapa jenis mikroba di dalam rumen sehingga produksi gas turun [20, 21, 22]. Semakin cepat suatu pakan didegradasi semakin baik mutu pakan tersebut sehingga dapat meningkatkan intake (konsumsi pakan) serta produktifitas ternak.

Tabel 1. Rata-rata produksi gas selama 2, 4, 6, 8, 10, 12, 24, 48, 72 dan 96 jam inkubasi

\begin{tabular}{|c|c|c|c|c|c|c|c|c|c|c|}
\hline \multirow{2}{*}{ Perlakuan } & \multicolumn{10}{|c|}{ Lama inkubasi (jam) } \\
\hline & 2 & 4 & 6 & 8 & 10 & 12 & 24 & 48 & 72 & 96 \\
\hline A & $7,34^{\mathrm{ab}}$ & $13,77^{\mathrm{ab}}$ & $19,59^{\mathrm{ab}}$ & $24,85^{\mathrm{ab}}$ & $29,48^{\mathrm{ab}}$ & $33,80^{\mathrm{a}}$ & $52,35^{\mathrm{bc}}$ & $68,15^{\text {def }}$ & $72,94^{\mathrm{d}}$ & $74,39^{\mathrm{c}}$ \\
\hline B & $6,89^{\mathrm{a}}$ & $12,92^{\mathrm{a}}$ & $18,47^{\mathrm{a}}$ & $23,57^{\mathrm{a}}$ & $28,06^{\mathrm{a}}$ & $32,39^{\mathrm{a}}$ & $52,07^{\mathrm{b}}$ & $71,75^{f}$ & $\mathbf{7 9}, 59^{\mathrm{e}}$ & $82,84^{c}$ \\
\hline $\mathrm{C}$ & $7,38^{\mathrm{ab}}$ & $13,69^{\mathrm{ab}}$ & $19,26^{\mathrm{ab}}$ & $24,20^{\mathrm{ab}}$ & $28,42^{\mathrm{ab}}$ & $32,30^{\mathrm{a}}$ & $47,79^{\mathrm{a}}$ & $58,88^{\mathrm{ab}}$ & $61,52^{\mathrm{ab}}$ & $62,15^{\mathrm{ab}}$ \\
\hline $\mathrm{D}$ & $9,09^{\mathrm{de}}$ & $16,8^{\text {de }}$ & $23,50^{\mathrm{de}}$ & $29,33^{\text {de }}$ & $34,29^{\mathrm{cd}}$ & $38,72^{\mathrm{bc}}$ & $55,55^{\mathrm{de}}$ & $66,12^{\text {cde }}$ & $68,16^{\mathrm{cd}}$ & $68,57^{\text {bc }}$ \\
\hline $\mathrm{E}$ & $8,55^{\mathrm{cd}}$ & $15,9^{\mathrm{cd}}$ & $22,36^{\mathrm{cd}}$ & $28,05^{\mathrm{cd}}$ & $32,95^{\mathrm{c}}$ & $37,35^{\mathrm{b}}$ & $54,62^{\mathrm{cd}}$ & $66,34^{\text {cde }}$ & $68,88^{\mathrm{cd}}$ & $69,44^{\text {bc }}$ \\
\hline $\mathrm{F}$ & $8,01^{\mathrm{bc}}$ & $14,79^{\mathrm{bc}}$ & $20,75^{\mathrm{bc}}$ & $26,01^{b c}$ & $30,47^{\mathrm{b}}$ & $34,56^{\mathrm{a}}$ & $50,64^{\mathrm{b}}$ & $61,60^{\mathrm{bc}}$ & $63,99^{\mathrm{bc}}$ & $64,50^{b}$ \\
\hline $\mathrm{G}$ & $8,02^{b c}$ & $14,63^{\mathrm{bc}}$ & $20,34^{\mathrm{ab}}$ & $25,27^{\mathrm{ab}}$ & $29,35^{\mathrm{ab}}$ & $33,04^{\mathrm{a}}$ & $46,76^{\mathrm{a}}$ & $54,92^{\mathrm{a}}$ & $56,40^{\mathrm{a}}$ & $56,67^{\mathrm{a}}$ \\
\hline $\mathrm{H}$ & $9,61^{\mathrm{e}}$ & $17,52^{\mathrm{e}}$ & $24,39^{\mathrm{e}}$ & $30,39^{\mathrm{e}}$ & $35,34^{d}$ & $39,93^{\mathrm{c}}$ & $\mathbf{5 7 , 5 9 ^ { \mathrm { e } }}$ & $69,26^{\mathrm{ef}}$ & $71,81^{\mathrm{d}}$ & $72,38^{\mathrm{c}}$ \\
\hline I & $7,12^{\mathrm{a}}$ & $13,52^{\mathrm{ab}}$ & $19,25^{\mathrm{ab}}$ & $24,38^{\mathrm{ab}}$ & $28,98^{\mathrm{ab}}$ & $33,10^{\mathrm{a}}$ & $50,33^{\mathrm{b}}$ & $64,31^{\mathrm{cd}}$ & $68,46^{\mathrm{cd}}$ & $69,76^{\mathrm{bc}}$ \\
\hline
\end{tabular}

Keterangan: Superscript berbeda pada kolom yang sama menunjukkan perbedaan yang nyata $(\mathrm{P}<0,05)$ A: BKL/01/50, B: BKL/01/K, C: BKL/01/30, D: UP/40, E: UP/20, F: UPCASI (k), G: ET-35, H: ET-20 dan I= ET-25

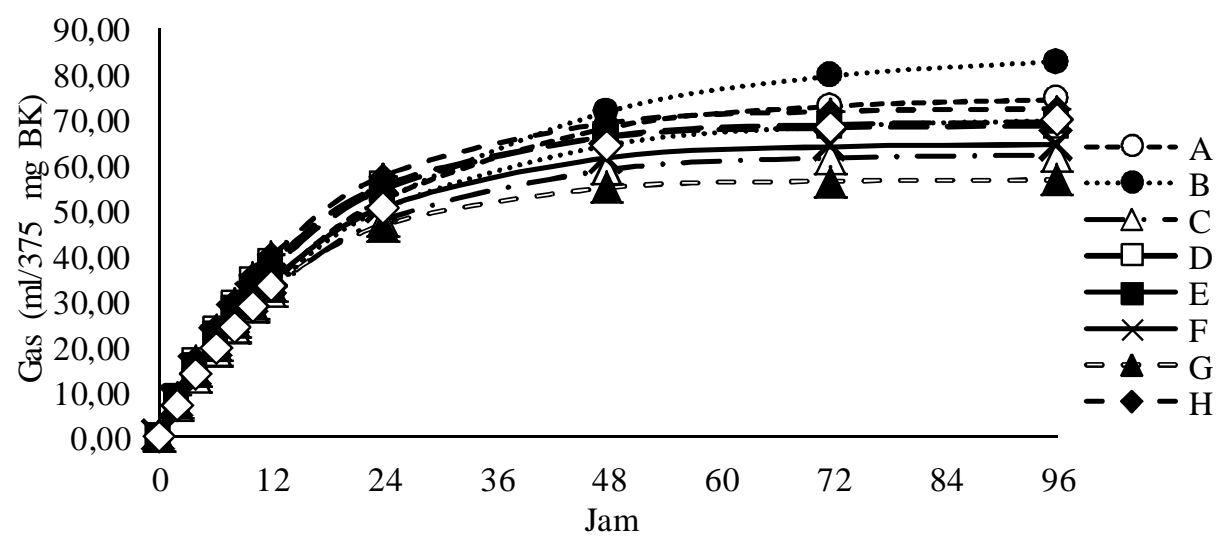

Gambar 1. Laju produksi gas sampai 96 jam inkubasi in-vitro (B: BKL/01/K, C: BKL/01/30, D: UP/40, E: UP/20, F: UPCASI (k), G: ET-35, H: ET20 dan $\mathrm{I}=\mathrm{ET}-25)$ 
Potensi $(\mathrm{a}+\mathrm{b})$ produksi gas yang dihasilkan juga berbeda nyata $(\mathrm{P}<0,05)$, dimana tertinggi BKL/01/k (perlakuan B) yaitu $85,46 \mathrm{ml}$ dengan laju produksi gas $(\mathrm{k})$ paling rendah yaitu 0,04 , sementara potensi terendah dihasilkan ET-35 (perlakuan G) yaitu $56,74 \mathrm{ml}$ dengan laju produksi gas yang lebih tinggi yaitu 0,07. Bila melihat rasio gas 24 jam dengan potensi produksi gas galur ET-35 setelah 24 jam inkubasi telah menghasilkan $82,45 \%$ gas, sehingga efisiensinya lebih tinggi dibandingkan dengan galur lainnya tidak berbeda nyata $(\mathrm{P}>0,05)$ dengan UP/40, UP/20, UPCASI (k), ET-20 dan ET-25, tetapi berbeda nyata $(\mathrm{P}<0,05)$ dengan $\mathrm{BKL} / 01 / \mathrm{k}$, BKL/01/50, dan BKL/01/30 yang menghasilkan presentase produksi gas rendah yaitu $62,24,69,77$ dan $76,75 \%$. dan F, sedangkan nilai DBO perlakuan D tidak berbeda nyata $(\mathrm{P}<0,05)$ dengan perlakuan $\mathrm{F}$ dan $\mathrm{H}$, sedangkan perlakuan $\mathrm{B}$ tidak berbeda nyata $(\mathrm{P}<0,05)$ dengan perlakuan $\mathrm{G}, \mathrm{H}$ dan I. Artinya degradabilitas galur sorghum UP/40, UPCASI (k) dan ET-20 secara nyata $(\mathrm{P}<0,05)$ lebih tinggi dibandingkan dengan perlakuan. Penurunan produksi gas juga menyebabkan penurunan laju degradabilitas [24]. Mikroba akan memanfaatkan nutrisi mudah larut terlebih dahulu di dalam rumen [25]. Laju degradabilitas bahan kering dan organik yang lebih tinggi sampai 24 jam inkubasi in-vitro pada perlakuan $\mathrm{D}, \mathrm{C}, \mathrm{E}$ dan $\mathrm{F}$ nilai kemanfaatan yang lebih tinggi, walaupun setelah 24 jam laju degradabilitas nya semakin menurun bila dibandingkan dengan perlakuan B dan A yang semakin naik. Kandungan total phenol, condensed

Tabel 2. Potensi dan laju produksi gas serta rasio gas 24 jam/potensi produksi gas

\begin{tabular}{cccc}
\hline Perlakuan & $\mathrm{a}+\mathrm{b}$ & $\mathrm{K}$ & $\begin{array}{c}\text { Gas } 24 \mathrm{jam} /(\mathrm{a}+\mathrm{b}) \\
(\%)\end{array}$ \\
\hline A & $75,03^{\mathrm{d}}$ & $0,0499^{\mathrm{ab}}$ & $69,77^{\mathrm{a}}$ \\
B & $\mathbf{8 5 , 4 6}^{\mathrm{e}}$ & $0,0417^{\mathrm{a}}$ & $62,24^{\mathrm{a}}$ \\
C & $62,37^{\mathrm{ab}}$ & $0,0612^{\mathrm{bc}}$ & $76,75^{\mathrm{a}}$ \\
D & $68,67^{\mathrm{bcd}}$ & $0,0695^{\mathrm{c}}$ & $80,98^{\mathrm{b}}$ \\
E & $69,59^{\mathrm{bcd}}$ & $0,0644^{\mathrm{c}}$ & $78,54^{\mathrm{b}}$ \\
F & $64,64^{\mathrm{bcc}}$ & $0,0638^{\mathrm{c}}$ & $78,35^{\mathrm{b}}$ \\
G & $56,74^{\mathrm{a}}$ & $\mathbf{0 , 0 7 3 2}^{\mathbf{c}}$ & $\mathbf{8 2 , 4 5}^{\mathbf{b}}$ \\
H & $72,56^{\mathrm{c}}$ & $0,0688^{\mathrm{c}}$ & $79,83^{\mathrm{b}}$ \\
I & $70,43^{\text {bcd }}$ & $0,0546^{\mathrm{c}}$ & $78,69^{\mathrm{b}}$ \\
\hline
\end{tabular}

Keterangan : Superscript berbeda pada kolom yang sama menunjukkan perbedaan yang nyata (P<0,05) A: BKL/01/50, B: BKL/01/K, C: BKL/01/30, D: UP/40, E: UP/20, F: UPCASI (k), G: ET-35, H: ET-20 dan I=ET-25

\section{Degradabilitas}

Pada Tabel 3 dapat dilihat nilai degradabilitas bahan kering (DBK) setelah 24 jam inkubasi in-vitro berbeda nyata $(\mathrm{P}<0,05)$, dimana tertinggi dihasilkan galur UP/40 (perlakuan D) yaitu $54,45 \%$, terendah dihasilkan BKL/01/K (perlakuan B) yaitu 50,31\%, demikian juga dengan hasil uji keragaman degradabilitas bahan organik (DBO) antar perlakuan diperoleh perbedaan yang nyata pada hasil $(\mathrm{P}<0,05)$ dimana galur mutan UP/40 (perlakuan D) menghasilkan degradabilitas bahan kering tertinggi yaitu $54,13 \%$, sementara terendah dihasilkan galur mutan BKL/01/K (perlakuan B) yaitu 50,31\%.

Setelah dilakukan uji lanjutan beda nyata terkecil (BNT) nilai DBK perlakuan D tidak berbeda nyata $(\mathrm{P}<0,05)$ dengan perlakuan $\mathrm{C}, \mathrm{E}$ tannin, saponin and mangan dalam jumlah yang besar akan menghambat laju degradabilitas, tetapi dengan pemakaian yang tepat dapat memodifikasi fungsi rumen [26]. Moringa oleifera dapat meningkatkan nilai degradabilitas walaupun juga mengandung anti nutrisi seperti moringin dan tanin [25]. Anti nutrisi biasanya ditemukan pada bahan pakan sumber protein dalam jumlah berbeda [27].

Laju degradasi bahan kering (DBK) yang dihasilkan berbeda nyata $(\mathrm{P}<0,05)$ diantara perlakuan, dimana nilai tertinggi setelah 48 jam inkubasi in-vitro diperoleh perlakuan A yaitu $67,31 \%$, terendah perlakuan $\mathrm{G}$ yaitu $58,93 \%$. Hasil yang berbeda diperoleh setelah 24 jam inkubasi, dimana nilai DBK tertinggi dihasilkan perlakuan D yaitu $54,45 \%$, dan terendah perlakuan 
Tabel 3. Rata-rata degradabilitas bahan kering (DBK) pada 2, 4, 6, 8, 10,12, 24, 48, 72 dan 96 jam inkubasi In vitro

\begin{tabular}{|c|c|c|c|c|c|c|}
\hline \multirow{2}{*}{ Perlakuan } & \multicolumn{6}{|c|}{ Lama inkubasi (jam) } \\
\hline & 2 & 4 & 8 & 12 & 24 & 48 \\
\hline $\mathrm{A}$ & $7,18^{\mathrm{ab}}$ & $13,66^{b}$ & $24,78^{b}$ & $33,84^{b}$ & $52,11^{b}$ & $67,31^{d}$ \\
\hline B & $6,12^{\mathrm{a}}$ & $11,80^{\mathrm{a}}$ & $21,95^{\mathrm{a}}$ & $30,69^{\mathrm{a}}$ & $50,31^{\mathrm{a}}$ & $67,12^{\mathrm{d}}$ \\
\hline $\mathrm{C}$ & $8,14^{\mathrm{c}}$ & $15,33^{\mathrm{cd}}$ & $27,31^{\mathrm{cd}}$ & $36,66^{\mathrm{de}}$ & $54,17^{\mathrm{d}}$ & $66,68^{\text {cd }}$ \\
\hline $\mathrm{D}$ & $8,55^{\mathrm{c}}$ & $16,03^{d}$ & $28,27^{d}$ & $37,63^{\mathrm{e}}$ & $54,45^{d}$ & $65,37^{\mathrm{bcd}}$ \\
\hline $\mathrm{E}$ & $8,12^{\mathrm{c}}$ & $15,29^{\mathrm{cd}}$ & $27,22^{\text {cd }}$ & $36,53^{\text {de }}$ & $53,88^{\mathrm{d}}$ & $66,05^{\mathrm{cd}}$ \\
\hline $\mathrm{F}$ & $8,21^{\mathrm{c}}$ & $15,43^{\mathrm{cd}}$ & $27,41^{\text {cd }}$ & $36,70^{\text {de }}$ & $53,84^{\text {cd }}$ & $65,59^{\mathrm{bcd}}$ \\
\hline $\mathrm{G}$ & $8,60^{c}$ & $15,98^{\mathrm{cd}}$ & $27,73^{\mathrm{cd}}$ & $36,37^{\text {cde }}$ & $50,85^{\mathrm{a}}$ & $58,93^{\mathrm{a}}$ \\
\hline $\mathrm{H}$ & $8,20^{\mathrm{c}}$ & $15,30^{\mathrm{cd}}$ & $26,81^{\mathrm{cd}}$ & $35,51^{\mathrm{bcd}}$ & $50,98^{\mathrm{ab}}$ & $61,14^{\mathrm{ab}}$ \\
\hline I & $7,74^{\mathrm{bc}}$ & $14,57^{\mathrm{bc}}$ & $25,89^{b c}$ & $34,70^{\mathrm{bc}}$ & $51,05^{\mathrm{ab}}$ & $62,49^{\mathrm{abc}}$ \\
\hline
\end{tabular}

Keterangan: Superscript berbeda pada kolom yang sama menunjukkan perbedaan yang nyata $(\mathrm{P}<0,05)$ A: BKL/01/50, B: BKL/01/K, C: BKL/01/30, D: UP/40, E: UP/20, F: UPCASI (k), G: ET-35, H: ET-20 dan I= ET-25

B yaitu 50,31\%. Hasil uji lanjut LSD menunjukkan perlakuan $\mathrm{D}$ tidak berbeda nyata $(\mathrm{P}>0,05)$ dengan perlakuan $\mathrm{C}, \mathrm{E}$ dan $\mathrm{F}$. Maka perlakuan D, C, E dan $\mathrm{F}$ lebih baik jika dimanfaatkan sebagai pakan ternak, karena nilai degradabilitas sampai 24 jam inkubasi in-vitro lebih tinggi, sementara itu perlakuan A dan B masih memiliki potensi sebagai pakan ternak, karena perlakuan B pada 48, 72 dan 96 jam inkubasi menghasilkan DBK tertinggi, dan tidak berbeda nyata $(\mathrm{P}>0,05)$ dengan perlakuan $\mathrm{A}$.

Laju degradasi bahan organik (DBO) yang tertinggi diperoleh setelah 48, 72 dan 96 jam adalah 69,13\% (B); 75,03\% (B) dan 77,08\% (B). Nilai DBO terendah setelah 48, 72 dan 96 jam inkubasi adalah 58,72\% (G); 60,01\% (G); 60,22\% (G). Terlihat perbedaan nilai degradabilitas setelah 48, 72 dan 96 jam dengan 24 jam inkubasi, dimana setelah 24 jam nilai tertinggi perlakuan D yaitu $54,45 \%$ yang tidak berbeda nyata $(\mathrm{P}>0,05)$ dengan perlakuan F. Secara umum perlakuan D dan $\mathrm{F}$ lebih baik jika dimanfaatkan sebagai pakan ternak, karena nilai degradabilitas bahan organik sampai 24 jam inkubasi in-vitro paling tinggi, sementara itu perlakuan A dan B masih memiliki potensi sebagai pakan ternak, karena perlakuan B pada 48, 72 dan 96 jam inkubasi menghasilkan DBO tertinggi, dan tidak berbeda nyata $(\mathrm{P}>0,05)$ dengan perlakuan A. Mikroba di dalam rumen akan memfermentasi zat nutrisi terlarut terlebih dahulu, untuk perkembangan mikroba, sehingga degradasi pakan menjadi lebih cepat [25].

Nilai tertinggi DBO setelah 48 jam adalah galur BKL/01/K (perlakuan B) yaitu $69,13 \%$ yang tidak berbeda nyata $(\mathrm{P}<0,05)$ dengan perlakuan $\mathrm{A}$. Data ini menunjukkan nilai degradabilitas

Tabel 4. Rata-rata degradabilitas bahan organiks (DBO) pada 2, 4, 6, 8, 10,12, 24, 48, 72 dan 96 jam inkubasi In vitro

\begin{tabular}{|c|c|c|c|c|c|c|}
\hline \multirow{2}{*}{ Perlakuan } & \multicolumn{6}{|c|}{ Lama inkubasi (jam) } \\
\hline & 2 & 4 & 8 & 12 & 24 & 48 \\
\hline $\mathrm{A}$ & $7,69 \mathrm{~s}^{\mathrm{bc}}$ & $13,39^{\mathrm{ab}}$ & $24,29^{\mathrm{ab}}$ & $33,17^{\mathrm{ab}}$ & $51,08^{\mathrm{abc}}$ & $65,97^{\mathrm{cd}}$ \\
\hline B & $6,30^{\mathrm{a}}$ & $12,14^{\mathrm{a}}$ & $22,60^{\mathrm{a}}$ & $31,60^{\mathrm{a}}$ & $51,83^{\text {bcd }}$ & $69,13^{d}$ \\
\hline $\mathrm{C}$ & $7,90^{\mathrm{bc}}$ & $14,75^{\mathrm{bc}}$ & $26,25^{\mathrm{bcd}}$ & $35,23^{\mathrm{cd}}$ & $52,02^{\mathrm{cd}}$ & $63,99^{\mathrm{bc}}$ \\
\hline $\mathrm{D}$ & $8,50^{\mathrm{c}}$ & $15,93^{\mathrm{c}}$ & $28,11^{d}$ & $37,41^{\mathrm{e}}$ & $54,13^{\text {f }}$ & $64,99^{c}$ \\
\hline E & $7,83^{\mathrm{bc}}$ & $14,88^{\mathrm{c}}$ & $26,49^{\mathrm{cd}}$ & $35,54^{\text {cd }}$ & $52,42^{\text {de }}$ & $64,26^{\mathrm{bc}}$ \\
\hline $\mathrm{F}$ & $8,12^{\mathrm{c}}$ & $15,28^{\mathrm{c}}$ & $27,13^{\mathrm{cd}}$ & $36,33^{\text {cd }}$ & $53,30^{\text {ef }}$ & $64,94^{\mathrm{c}}$ \\
\hline $\mathrm{G}$ & $\mathbf{8}, 58^{c}$ & $15,93^{\mathrm{c}}$ & $27,64^{\mathrm{cd}}$ & $36,25^{\mathrm{cd}}$ & $50,67^{\mathrm{a}}$ & $58,72^{\mathrm{a}}$ \\
\hline $\mathrm{H}$ & $8,53^{\mathrm{c}}$ & $15,93^{\mathrm{c}}$ & $27,92^{d}$ & $36,98^{\mathrm{de}}$ & $50,92^{\mathrm{abc}}$ & $63,71^{\mathrm{bc}}$ \\
\hline I & $7,04^{\mathrm{ab}}$ & $14,47^{\mathrm{bc}}$ & $25,71^{\mathrm{bc}}$ & $34,45^{\mathrm{bc}}$ & $50,69^{\mathrm{ab}}$ & $62,05^{\mathrm{ab}}$ \\
\hline
\end{tabular}

Keterangan: A: BKL/01/50, B: BKL/01/K, C: BKL/01/30, D: UP/40, E: UP/20, F: UPCASI (k), G: ET-35, H: ET-20 dan I=ET-25 
maksimum setelah 48 jam inkubasi. Terlihat perbedaan nilai degradabilitas setelah 48 jam dengan 24 jam inkubasi, dimana setelah 24 jam nilai tertinggi perlakuan D yaitu $54,13 \%$ yang tidak berbeda nyata $(\mathrm{P}>0,05)$ dengan perlakuan $\mathrm{F}$. Perlakuan A dan B masih memiliki potensi sebagai pakan ternak yang baik, karena perlakuan B dari 48, 72 sampai 96 jam inkubasi menghasilkan degradabilitas tertinggi dan tidak berbeda nyata $(\mathrm{P}>0,05)$ dengan perlakuan $\mathrm{A}$.

Kandungan protein yang tinggi dapat dimanfaatkan oleh mikroba untuk sintesis protein mikroba, sedangkan kandmungan anti nutrisi pada jerami dan daun sorgum dapat mempertahankan laju degradabilitas di dalam rumen. Protein pakan yang lolos dari degradabilitas dalam rumen akan dapat dicerna dengan baik secara enzimatik di dalam saluran pencernaan ruminansia. Jerami dan daun sorgum mengandung protein sampai $15,6 \%$ $[11,12]$. Peningkatan biomassa mikroba di dalam rumen dengan ketersediaan nitrogen dan karbohidrat secara langsung akan meningkatkan nilai degradabilitas pakan [25].

\section{KESIMPULAN}

Perlakuan $\mathrm{H}$ menghasilkan gas tertinggi pada $2 ; 4 ; 6 ; 8 ; 10 ; 12$ dan 24 jam inkubasi yaitu 9,$61 ; 17,52 ; 24,39 ; 30,39 ; 35,34 ; \quad 39,93$ dan $57,59 \mathrm{ml} / 375 \mathrm{mg} \mathrm{BK}$ secara berturut-turut.

Sorgum terbaik yang mempunyai degradabilitas tinggi sampai 24 jam inkubasi adalah galur mutan sorgum BKL/01/30, UP/40, UP/20, UPCASI (k) (perlakuan C, D, E dan F).

Perlakuan BKL/01/50, BKL/01/K, ET-20 dan ET-25 (A, B, H dan I) sangat cocok dipakai untuk pakan by-pass setelah rumen, karena degradabilitas yang rendah sampai 24 jam inkubasi in-vitro.

Perlakuan G (Galur ET-35) perlu dilakukan penelitian lebih lanjut tentang kandungan zat anti nutrisi.

\section{UCAPAN TERIMA KASIH}

Penulis mengucapkan terima kasih kepada seluruh staf laboratorium Nutrisi Ternak Bidang Pertanian PAIR BATAN atas bantuan teknis selama penelitian.

\section{DAFTAR PUSTAKA}

1. Williams, B.A., Cumulative Gas-production Techniques for Forage Evaluation. In: Givens, D.I., E. Owen., R.F.E. Axford and H.M. Omed, Forage Evaluation in Ruminant Nutrition, CABI Publishing, London - UK. ISBN 085199344 3. P 189-205, 2000.

2. Makkar, H.P.S., Applications Of The In Vitro Gas Method In The Evaluation Of Feed Resources, And Enhancement Of Nutritional Value of Tannin-Rich Tree/Browse Leaves And AgroIndustrial By-Products., in: IAEA Tecdoc 1294, "Development and field evaluation of animal feed supplementation packages" International Atomic Energy Agency. P 23 - 35, 2002.

3. Krishnamoorthy, U., "RCA Training Workshop on In-vitro Techniques for Feed Evaluation". The International Atomic Energy Agency, Vienna, Austria. P 8 - 26, 2001.

4. Blummel, M., Makkar, H.P.S., Becker, K., The Invitro Gas Production: A Technique Revisited. J, Anim. Phys. And Nutr. vol. 77, pp. 24-34, 1997.

5. Aghsaghali, A.M., Sis, N.M., Mansouri, H., Razeghi, M.E., Shayegh, J., Golshani, A.A., Evaluating nutritional value of apple pomace for ruminants using in vitro gas production technique, Annals of Biological Research, 2 (1) ISSN 0976-1233 : 100-106, 2011.

6. Jayanegara A, Sofyan A., Penentuan aktivitas biologis tanin beberapa hijauan secara in vitro menggunakan 'Hohenheim gas test' dengan polietilen glikol sebagai determinan. Media Peternakan, vol. 31, pp. 44-52, 2008.

7. Sofyan. A, dan A. Jayanegara, 2008, Gas Test: Lebih Cepat Ukur Kecernaan Pakan Ruminansia, Majalah Agribisnis Peternakan \& Perikanan TROBOS Edisi 111, Desember, 2008. 
8. Sirappa, M.P., Prospek Pengembangan Sorgum di Indonesia sebagai Komoditas Alternatif untuk Pangan, Pakan, dan Industri. J. Litbang Pertanian, vol. 22, pp. 133-140, 2003.

9. Prihandana, R., Hendroko, R., Energi Hijau. Penebar Swadaya. Jakarta, 2008.

10. Widowati, S., Nurjanah, R., Amrinola, W., Proses Pembuatan dan Karakterisasi Nasi Sorgum Instan. Prosiding Pekan Serealia Nasional, ISBN : 978-9798940-29-3. P 35-48, 2010.

11. Blümmel, M., Vishala, A., Ravi, D., Prasad, K.V.S.V., Reddy, Ch.R., Seetharama, N.,Multi-environmental Investigations of Food-Feed Trait Relationships in Kharif and Rabi Sorghum (Sorghumbicolor (L) Moench) Over Several Years of Cultivars Testing in India, Animal Nutrition and Feed Technology 10S : 11-21, 2010.

12. Sharma, K., Pattanaik, A.K., Anandan, S., Blümmel, M., Food-Feed Crops Research: A Synthesis. Animal Nutrition and Feed Technology 10S : 1-10, 2010.

13. Purnomohadi, M., Potensi Penggunaan Beberapa Varietas Sorgum Manis (Sorghum bicolor (L.) Moench) Sebagai Tanaman Pakan. Berk. Penel. Hayati: 12, 41-44, 2006.

14. Koten, B.B., Soetrisno, R.D., Ngadiyono, N., Suwignyo, B., Produksi Tanaman Sorgum (Sorghum Bicolor (L.) Moench) Varietas Lokal Rote Sebagai Hijauan Pakan Ruminansia Pada Umur Panen Dan Dosis Pupuk Urea Yang Berbeda. Buletin Peternakan, vol. 36, no. 3, pp. 150-155, 2012.

15. Soeranto, H., Pemuliaan Mutasi Pada Sorghum (Sorghum Bicolor L.) untuk Perbaikan Tanaman Sebagai Pakan Ternak Ruminansia. Prosiding Pertemuan Ilmiah Aplikasi Isotop dan Radiasi. BATAN, 1998.
16. Sastrosupadi, A., Rancangan Percobaan Praktis Bidang Pertanian. Kanisius. Yogyakarta, 2000.

17. Chen, X.B., Neway Excel. A Utility for Processing Data of Feed Degradability and In vitro Gas Production (version 6 for office XP). International Feed Resources Unit, MLURI, Aberdeen, UK, 2004.

18. Sihono., Human, S., Indriatama, W.M., Puspitasari, W., Parno., Carkum., Galur Mutan Sorgum PATIR-1 Berdaya Hasil Biji, Biomasa dan Gula Batang Tinggi serta Galur PATIR-4 Hasil Biji Tinggi Kualitas Baik, Perbaikan Proposal Pelepasan Varietas, Pusat Aplikasi Isotop dan Radiasi, BATAN, 2013.

19. Rooney, L.W., Methods of Processing Sorghum for Livestock Feeds. Dalam Gomez, M.I., L.R. House, L.W. Rooney, and D.A.V. Dendy, Utilization of Sorghum and Millets., ICRISAT, India. pp. 167-170, 1992.

20. Firsoni. Pengaruh Pemakaian Chromolaena Odorata di Dalam Konsentrat Terhadap Produksi Gas Metana secara In-vitro. Prosiding Seminar Nasional Sinergi Pakan dan Energi Terbarukan. SPRINTLIPI. pp. 424-427, 2014.

21. Firsoni., Puspitasari, L., Andini, L., Efek Daun Paitan (Tithonia diversifolia (HEMSLEY) A. GRAY) dan Kelor (Moringa oleifera, LAMK) Di Dalam Pakan Komplit In-vitro, Prosiding Seminar Nasional Teknologi Peternakan dan Veteriner. ISBN 978-602-8475-46-4, 2011.

22. Hariadi, B.T., Santoso, B., Evaluation of tropical plants containing tannin on in vitro methanogenesis and fermentation parameters using rumen fluid. $J S C i$ Food Agric. Vol. 90, pp. 456-461, 2010.

23. Tan, H.Y., Sieo, C.C., Abdullah, N., Liang, J.B., Huang, X.D., Ho, Y.W., Effects of condensed tannins from Leucaena on methane production, rumen fermentation 
and populations of methanogens and protozoa in vitro, Animal Feed Science and Technology, vol. 169, pp. 185- 193, 2011.

24. McDonald, P., Edwards, R.A., Greenhalgh, J.F.D., MORGAN, C.A., SINCLAIR, L.A., Wilkinson, Animal Nutrition, $7^{\text {th }}$ Ed., Prentice Hall, Pearson, Harlow. England, London, 2010.

25. Khan, M.M.H., Chaudhry, A.S., Chemical Composition of Selected Forages and Spices and the Effect of These Spices on In vitro Rumen Degradability of Some Forages. Asian-Aust. J. Anim. Sci. vol. 23, No. 7, pp. 889-900, 2010.
26. Firsoni., Fortuna, C., Lisanti, E., Uji Kecernaan In-vitro Dedak Padi yang Mengandung Daun Paitan (Tithonia diversifolia (HEMSL.) A. Gray) dan Kelor (Moringa oleifera, Lamk)., Jurnal Ilmu Ternak Veterineer, vol. 15, no. 3, pp. 182-187, 2010.

27. Promkot, C., Wanapat, M., Rowlinson, P., Estimation of Ruminal Degradation and Intestinal Digestion of Tropical Protein Resources Using the Nylon Bag Technique and the Three-step In vitro Procedure in Dairy Cattle on Rice Straw Diets. Asian-Aust. J. Anim. Sci. vol. 20, no. 12, pp. 1849-1857, 2007. 
Jurnal Ilmiah Aplikasi Isotop dan Radiasi

A Scientific Journal for The Applications of Isotopes and Radiation

p ISSN 1907-0322

Vol. 13 No. 1 Juni 2017

e ISSN 2527-6433 